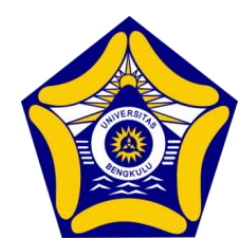

\title{
Analysis of Earthquakes Potential Damages as a Disaster Mitigation Effort
}

\author{
Alen Fezi Loveka*, Henny Johan, Rendy W. Wardana \\ Prodi S2 Pendidikan IPA, Universitas Bengkulu, Indonesia \\ *Email: alenfeziloveka22@gmail.com
}

DOI: https://doi.org/10.33369/bjset.2.1.20-23

\begin{abstract}
Muara Bangkahulu District is one of Bengkulu Province Subdistricts, which is used as a place for higher education service centers, government office centers, and community residential areas. Muara Bangkahulu has the risk of being affected by an earthquake caused by its geological conditions. To avoid the potential damage due to earthquake, the PGA parameters, seismic vulnerability index, ground shear strain, and thickness of sediment layer (h) were analyzed in Muara Bangkahulu District as an effort to mitigate earthquakes. The purpose of this study is to describe the potential damage caused by the earthquake in Muara Bangkahulu District as a disaster mitigation effort. This research was a qualitative descriptive study using the literature study method. The results of the literature study which showed the value of PGA produced between 184.22 gal to 532.92 gal. Distribution of seismic vulnerability index values between 0.56 to 7.95 . Distribution of ground shear strain values between $5.14 \times 10-5$ to $7.42 \times 10-4$. The thickness of the sediment layer (h) ranged from 8.13 meters to 61.31 meters. The largest PGA, IKS, GSS and $\mathrm{h}$ values are in Kualo Beach which is estimated to have a high level of risk for earthquake disasters with a correlation more than $74 \%$. Thus, it can be concluded that the vicinity of Kualo Beach is the most potential and prone to earthquake damage.
\end{abstract}

Keywords: PGA; Seismic Vulnerability Index; Ground Shear Strains; Thickness of Sedimentary Layer; Disaster mitigation.

\section{INTRODUCTION}

Bengkulu Province is geographically located at position $101^{\circ} 1^{\prime}-103^{\circ} 46$ 'E and $2^{\circ} 16^{\prime}-5^{\circ} 13^{\prime}$ S, stretching parallel to Bukit Barisan and facing the Indian Ocean directly with a coastline of \pm 525 $\mathrm{km}$ and territorial area 48,075 $\mathrm{km} 2$, extending from the border of West Sumatra Province to the border of Lampung Province. (BPS, 2016). Bengkulu Province's position is flanked by a subduction zone (support) between the Indian-Australian and Euro-Asian plates in the west and the Sumatra fault zone in the east (Lubis and Hasima, 2012). This condition causes Bengkulu to be very vulnerable to earthquake disasters. Bengkulu since 2000 has been shaken twice by large-scale tectonic earthquakes in 2000 and 2007. According to BMKG data, on June 4, 2000, Bengkulu was shaken by a tectonic earthquake with a magnitude of 7.3 on the Richter Scale (SR). Then a big earthquake occurred again on September 12, 2007 with a magnitude of 7.9 SR (Supriani, 2009). This earthquake caused a lot of damage to residential buildings, offices, worship place, public facilities, and road infrastructure, electricity and clean water. One of the Districts in Bengkulu City that has a high level of risk by an earthquake is the Muara Bangkahulu sub-district (Refrizon, 2015).

Muara Bangkahulu District is one of Bengkulu Province Subdistricts, which is used as a place for higher education service centers, government office centers, and community residential areas. Muara Bangkahulu has the risk of being affected by an earthquake caused by its geological conditions (Refrizon, 2015). Febriani et al (2013) states that the closer an area to an earthquake source, then the damage caused is even greater, but this also depends on the local geology which has a very significant effect on the damage caused by the earthquake to buildings. Buildings that are heavily damaged (collapsed) are usually caused by unstable earth layers / rocks, which are related to the density of a rock, therefore earthquakes will give a visual impact on the surface and structure systems at the surface of the soil, in the form of earthquake intensity. With a potential earthquake area, earthquake disaster can come suddenly, effort and anticipation of a disaster in the future is needed. 
One way to mitigate is by knowing the parameters of the PGA value, IKS, GSS, and sediment layer thickness. It is necessary for disaster mitigation efforts to determine the potential damage due to earthquakes andthe dangers of earthquake. Based on the study above, it is considered necessary to conduct a research about analyzing the potential for earthquake damage in Muara Bangkahulu District as a disaster mitigation effort.

\section{RESEARCH METHODS}

The research method used descriptive descriptive research. Descriptive qualitative research method is a research that is intended to investigate the circumstances, conditions, things that have been mentioned, that the results are presented in a research report (Sugiyono, 2015). The data used were secondary data by analyzing from literature studies. This descriptive research method by means of literature study by analyzing the level of potential for earthquake vulnerability in Muara Bangkahulu District, the parameters analyzed are the PGA, IKS, GSS, and sediment layer thickness.

\section{RESULTS AND DISCUSSION}

The study was conducted by analyzing the potential for earthquake damage in the Muara Bangkahulu District and a map of the location of the Muara Bangkahulu District. Farid's research (2017) explains that the map of shear strains with a scale of 1: 80,000 illustrates three conditions namely, potential and safe experience of severe damage if an earthquake occurs. Very potential to be given yellowcolor with a percentage around $35 \%$ and safe from damage being green color about $41 \%$. The damage caused by this strong potential is damage in the form of physical buildings, broken roads, broken bridges, landslides, tsunamis, liquefaction, and others. In the data analysis table, the value of shear strain that can have an impact on the potential for severe damage is $>0.001$. According to Isihara (2009), defermation of soil layers that might occur when an earthquake occurs. Areas that have a higher potential for damage were the Tanah Patah Village, Lempuing Village, Berkas Village, Timur Indah Village, Lingkar Barat Village, Teluk Sepang Village, Padang Harapan Village, Pagar Dewa Village and Pematang Gubernur Village. These villages are spread in several sub-districts, namely Gading Cempaka District, Selebar District, Muara Bangkahulu District and Sungai Serut District. The areas that have a potential damage being given red color of about 24\%, as shown in Figure 1 below:

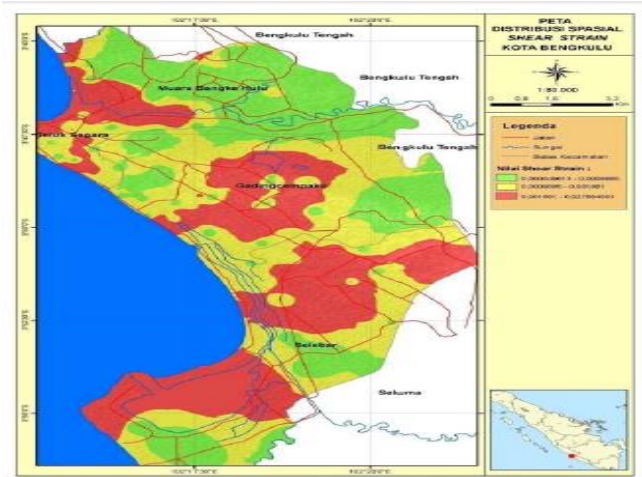

Figure 1. Map of research location. Source: (Farid, 2017)

Research (Singgalang et al., 2018),WRSupratman Road is one of the Muara Bangkahulu subdistrict areas. To know the characteristics and structure of subsurface layers of WR Supratman Road using the HVSR microtremor method with the spread value of PGA, IKS, and Vs30 subdistricts and the Wenner 2D resistivity geoelectric method. The study was conducted on 3 geoelectric trajectories with 9 microtremor measurement points. After the field data is obtained, the data were processed using Geopsy software on the microphone and Res2Dinv software on the geoelectric. Based on the cross section of the geoelectric structure on the 3 trajectories, the distribution of soft subgrade is mostly on the trajectory 1 with a resistivity value of $3.13 \Omega \mathrm{m}-24.5 \Omega \mathrm{m}$ which is interpreted as a layer of soft clay and spread to a depth of $\pm 6 \mathrm{~m}$. Based on HVSR microtremor measurements, the PGA value distribution was obtained between 523.03 gal - 774.94 gal. The distribution of seismic vulnerability index values ranged from $0.613-2.538$. The distribution of shear wave velocity values of 30 meters with ranged from $325.65 \mathrm{~m} / \mathrm{s}-463.19 \mathrm{~m} / \mathrm{s}$. From the three 
parameters, it is found that the area which has a high level of risk for earthquake disaster. Therefore, in this area, road pavement needs to be built more optimally in order to optimize working life.

The study (Merserina, et al, 2018) stated that microseismic research had been done in Muara Bangkahulu Subdistrict (parallel to the coastline) with a denser measurement point of 26 points from November to January 2017. The study was conducted to determine soil characteristics and the maximum result of distribution of ground vibration acceleration values (PGA), seismic susceptibility index (IKS), ground shear strain (GSS) and sediment layer thickness (H). The data collection process was done with a seismometer with a recording time of 30 minutes. The data is processed using Geopsy software with the analysis of the HVSR method. The calculation of PGA value uses the equation according to the Kanai and Fukushima methods for the earthquake data on September 12, 2007 with 8.5 Mw. The PGA value produced according to the Kanai method ranged from 745 to 198 gal and the PGA value produced according to the Fukushima method ranged from 22.38 to 22.23 gal. The distribution values ranges from 2.054 to 0.1 . The distribution of GSS values ranged from $9.48 \times$ 10 to $1.04 \times 10$ and the distribution of $\mathrm{H}$ values ranged from 3.97 to 56.7 meters. Kualo Beach area is an area of soft rock type or the area around the swamp (alluvial) has a large value for each indicator which means it has a high level of risk or prone to earthquake disasters.

Bengkulu City has a PGA value that varies from 292 gal to 852 gal and a seismic vulnerability value from 0.3 to 20.8. PGA value and seismic vulnerability index will be used to give recommendations in regional planning in the study area, to minimize the level of damage, as well as victims of earthquake that will occur (Febriani, 2013). This can be seen from the mapping of PGA and IKS values contained in the figures 2 and 3.

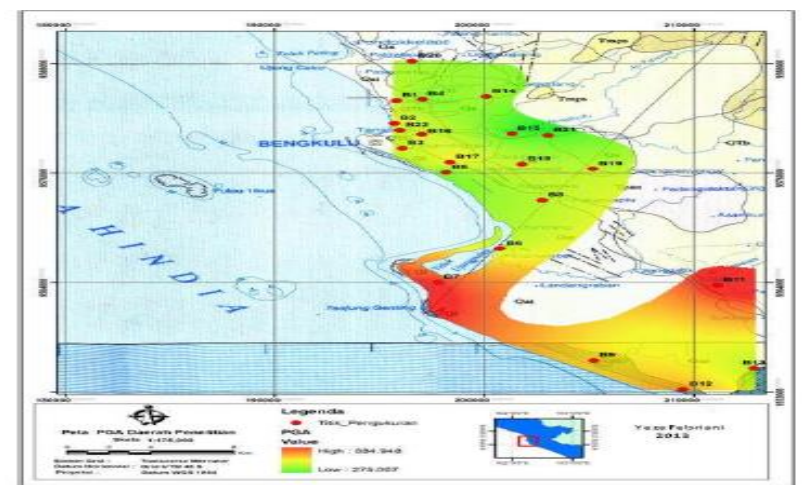

Figure 2. MAP of PGA values

Source: (Febriani, 2013)

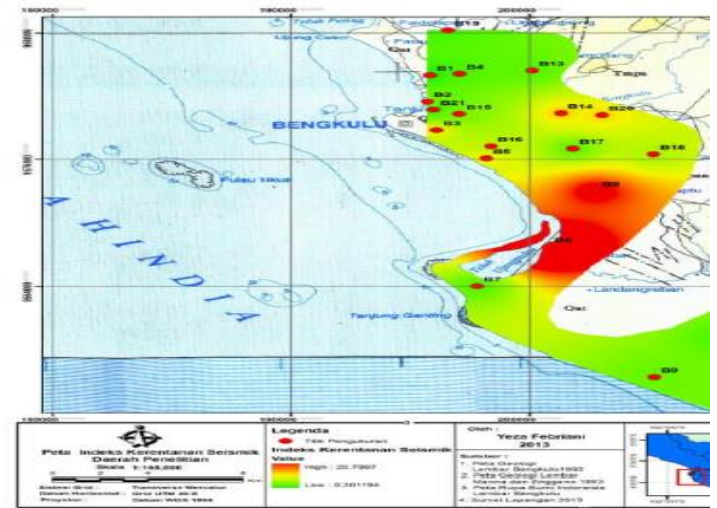

Figure 3. Map of IKS values Source: (Febriani, 2013)

Microroseismic research has been carried out in Muara Bangkahulu Subdistrict as many as 14 measurement points(Refrizon, 2015). The parameters obtained are PGA values between 184.22 gal to 532.92 gal. Distribution of seismic vulnerability index values between 0.56 to 7.95 . Distribution of ground shear strain values between $5.14 \times 10-5$ to $7.42 \times 10-4$. The thickness of the sediment layer $(\mathrm{h})$ ranged from 8.13 meters to 61.31 meters. The largest PGA, IKS, GSS and $h$ values are in Kualo Beach which is estimated to have a high level of risk for earthquake disasters with a correlation of> $74 \%$. The relationship graph of PGA, IKS, GSS, and h values is shown in figure 4.

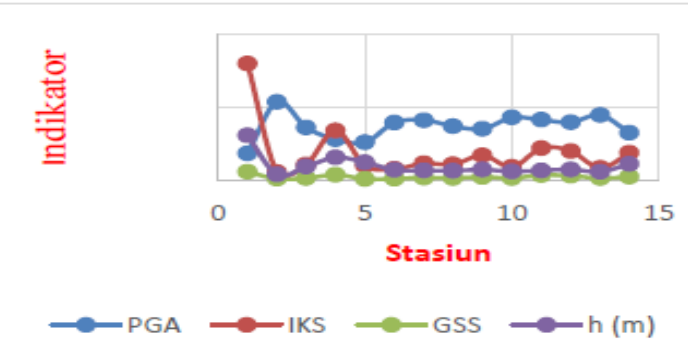

Figure 4. Relationship graph of PGA, IKS, GSS, and h 
From the analysis of literature study, it was found that the potential for damage due to the earthquake in Muara Bangkahulu Subdistrict was the Kualo coastal area. This is in accordance with Nakamura's (2016) study. It is known that coastal areas which are alluvial and reclamation plains have high seismic vulnerability index. The results of studies that have analyzed each indicator states that the large value of PGA, IKS, GSS and the thickness of sediment layer will have a high level of risk of earthquake disasters that will experience severe damage to the building if an earthquake occurs.

\section{CONCLUSIONS}

Based on the results of research analysis of literature studies conducted in the Muara Bangkahulu District, the potential for damage of the earthquake was very large, especially in the Kualo Coast area. It can be seen from the largest PGA, IKS, GSS and h values are in Kualo Beach which is estimated to have a high level of risk for earthquake disasters with a correlation of more than $74 \%$. For the installation of a high-rise building in this area, it is recommended that the depth of the foundation of the pile made must exceed the depth of the second layer or about 8-15 meters.

\section{REFERENCES}

BPS. (2016). Posisi Geografis Provinsi Bengkulu, Bengkulu.

Farid, M. (2017) Mitigasi bencana gempabumi menggunakan indikator shearstrain untuk mendukung tata ruang Kota Bengkulu (Penelitian Hibah Pasca Doktor).

Febriani, Y., Daruwati, I.,Hatika, R.G. (2013) Analisis nilai peak ground acceleration dan indeks kerentanan seismik berdasarkan data mikroseismik pada daerah rawan gempabumi di kota Bengkulu Vol (2).

Ishira. (2009) Introduction to Dynamic Soil Mechanism. Japan.

Lubis, A. M., Hashima, A. and Sato, T. (2012) Analysis of afterslip distributionfollowing the 2007 September 12southern Sumatra earthquake usingporoelastic and viscoelastic media,Geophys. $J$. Int. doi:10.1093/gji/ggs020.

Marserina, R., Refrizon, Budi, H. (2018) Upaya mitigasi gempabumi berdasarkan studi mikroseismik di Kecamatan Muara Bangkahulu (Sejajar dengan garis pantai).

Nakamura, Y. (2016) Seismic Vulnerability Indices For Ground and Structures Using Microtremor. World Congress on Railway Research in Florence. Italy.

Refrizon, Suhendra., Irkhos., Manurung,Y.S. (2015) Studi site effect dengan indikator percepatan getaran tanah maksimum, indeks kerentanan seismik, ground shear strain, dan ketebalan lapisan sedimen di Kecamatan Muara Bangkahulu 11 (2), 1122-1127.

Singgalang, D. R., Farid, M., Refrizon. (2018) Identifikasi karakteristik dan struktur lapisan bawah permukaan jalan WR. Supratman Kota Bengkulu menggunakan metode mikrotremor HVSR dan geolistrik resistivitas

Sugiyono. (2015) Metode penelitian kuantitatif, kualitatif, dan R\&D. Alfabeta: Bandung

Supriani. (2009) Studi mitigasi gempa di Bengkulu dengan membangun rumah tahan gempa Vol. 1, No.1 